\title{
THE SYNODICON OF THE BULGARIAN TSAR BORIL ${ }^{1}$
}

\section{Abstract:}

The paper examines a unique relic from the history and culture of medieval Bulgaria: the Synodicon of Tsar Boril from 1211. It is thought that the text is a translation of the Byzantine Synodicon from 843, created in Constantinople to honor a victory over Iconoclasm. The supplemented Bulgarian translation was first made in Bulgaria by order of Tsar Boril, who convened a Synod against the Bogomils in the Bulgarian capital, the city of Tarnovo in 1211. Two copies of the Synodicon are available: Palauzov's from the 14 th century and Drinov's from the 16th century. Both copies contain not only anathemas against heretics, but also evidence of the Bulgarians' historical memory about their past and some outstanding personalities: Saints Cyril and Methodius, the rulers of the First and Second Bulgarian Tsardoms and the patriarchs.

\section{Keywords:}

Medieval Bulgaria, Tsar Boril, Synodicon, synod against the Bogomils, Palauzov's copy, Drinov's copy, historical memory.

\section{АнНОтация: А.С. ДОБЫчИНА, «СИНОДИК БОЛГАРСКОГО цАРя БОРИЛА».}

В статье рассматривается уникальный памятник истории и культуры средневековой Болгарии - Синодик царя Борила 1211 г. Принято считать, что его текст является переводом византийского Синодика 843 г., составленного в Константинополе в честь победы над иконоборчеством. Болгарский перевод с дополнениями был произведен по приказу царя Борила, который инициировал собор против богомилов в столице Болгарии Тырново в 1211 г. Синодик сохранился в двух списках: Палаузовском XIV в. и Дриновском XVI в. Оба списка содержат не только анафемы еретикам, но и свидетельства исторической памяти болгар о своем прошлом и его выдающихся личностях: свв. Кирилле и Мефодии, правителях Первого и Второго Болгарского царств и патриархах.

\section{Ключевые слова:}

Средневековая Болгария, царь Борил, Синодик, антибогомильский собор, Палаузовский список, Дриновский список, историческая память.

The Synodicon of Tsar Boril (1207-18) is a unique relic of the history and culture of the medieval Bulgarian kingdom. The text is considered to be a translation into Slavic of the Byzantine Synodicon of 843, composed in connection with the restoration of the veneration of icons after the period of iconoclasm. The supplemented Bulgarian translation was made at the order of Tsar Boril, who convened a Synod in the Bulgarian capital, the city of Tarnovo in 1211 in order to condemn and eradicate the Bogomil heresy which had spread throughout the Bulgarian lands.

\footnotetext{
1 The work was carried out with the financial support of the RFBR (grant № 18-512-76004).
} 
The compiler of the Synodicon made a number of serious changes to the Byzantine original, supplementing it not only with a description of the Synod but also with names and events from Bulgarian history. During the 13th and 14 th centuries, the details in the Synodicon were supplemented repeatedly, and this feature makes this relic a valuable source of information on the history of the Bulgarian medieval period.

As an ecclesiastical and liturgical text, the Synodicon was read on the Feast of Orthodoxy (the first Sunday of Great Lent) and was accompanied by ecclesiastical choral singing. Reading of the Synodicon during the liturgy was first introduced by Tsar Boril in 1211, but the Synodicon itself only acquired canonical status in 1235. A supplement to the memorial part of the Synodicon suggests that its reading continued during the first centuries after the Ottoman conquest of the Bulgarian lands.

The original of Tsar Boril's Synodicon has not survived, but its text was partially restored from two later copies. The first is the so-called Palauzov copy, named after its first publisher, the Russian-Bulgarian historian S. N. Palauzov (1818-72). The manuscript was obtained by his cousin, N. H. Palauzov (1819-99), from the Tarnovo collector of antiquity and merchant of apothecary goods, Stoyancho (Stefan) Ahtar. After the death of S. N. Palauzov, the document was moved to the Collection of Slavonic Manuscripts in the Sts Cyril and Methodius National Library of Sofia, Bulgaria, where it is preserved under № 289 (55). The Palauzov copy dates back to the end of the 14th century and contains the version of the Synodicon created under the rule of Bulgarian Tsar Ivan Asen II (1218-41), which was later supplemented at the time of Tarnovo patriarch Euthymius (1375-93).

The manuscript consists of three parts. The first is a text of the Synodicon of Tsar Boril written in so-called ustav, which is a uncial majuscule script, with the use of red cinnabar for initial letters. The second part, written in semi-italic letters, contains the decisions of the ecumenical councils. The third part is a Greek original of the Synodicon, from which the second part of the collection was translated. The sheets of the three parts are not sewn into a single whole; they are put together and placed between two wooden covers protected with leather. The scribe placed the sheets in a notebook, but it is impossible to establish how many sheets were in each book, as many of them are torn or mixed up.

Apart from the Slavonic text, the Palauzov copy also contains four notations of the chants that were to be sung in Greek, as evidenced by the Greek entries next to the notes. Above the main text there are additional musical notes in red ink, suggesting the possible direction of the melody. The first piece of music with the name of the composer, placed before the texts, has been lost. The aforementioned musical texts reveal the transitional nature of liturgical choral practice of the Bulgarian church, in which, after the 13th century, there exist elements of both the Middle Byzantine and Neo-Byzantine musical notation. 
The second copy of the Synodicon is named Drinov after its owner, the famous historian of Bulgarian origin, M. S. Drinov (1838-1906), to whom this document was presented by a compatriot from the town of Panagyurishte. The manuscript dates back to the 16th century; the name of the scribe is known: the grammarian Angelakus, who was probably a cleric from Western Bulgaria. Unlike the Palauzov copy, the Drinov copy bears traces of editorial work in line with the literary tradition of the Tarnovo Literary School. Currently, the Drinov copy is also stored in Bulgaria in the Collection of Slavonic Manuscripts in the Sts. Cyril and Methodius National Library of Sofia, where it is preserved under № 432 (634).

On the basis of both copies, the outstanding slavist, M.G. Popruzhenko, professor at the Novorossiysk and Sofia universities, partly recreated the text of the Bulgarian Synodicon, taking into account the fragments which have been irretrievably lost. Its first part, a glorification of the defenders of Orthodoxy, is called "Thanksgiving." After that follows an anathema to all its enemies, including the Bogomils, against whose doctrines the Synod of 1211 was convened. Then follow commemorations to the deceased, polychronions of the representatives of the ruling dynasty, those close to them and religious dignitaries. However, most precious is the original Bulgarian part, which consists of historical texts associated with the names of the most important figures in Bulgarian history.

In the section of the Synodicon entitled "The beginning of the Bulgarian Tsars," eternal memory is proclaimed to Prince Boris I (852-89), who baptized Bulgaria and who is symbolically referred to as the Tsar, to his son Simeon I (893-927), his grandson Tsar Peter I (927-69) and other rulers of the first Bulgarian Tsardom.

The second series of commemorations in the Synodicon is devoted to Sts. Cyril and Methodius and their Slavonic disciples and emphasizes the Orthodox character of the Slavonic liturgy and the fact that the Slavonic liturgy has been an integral part of the heritage of the Bulgarian people and its Church for many centuries. The third part of the historical section of the Synodicon is associated with the memory of the Asen brothers, who restored independent Bulgarian statehood after the period when the Bulgarian lands were under Byzantine rule (1018-1185). All three sections are summarized by the story of the convocation of the Church Council of 1211 by Tsar Boril, which concludes with an anathema to the Bogomils and a three-fold Polychronion to the Tsar, his entourage and clerics. The narrative of the Bulgarian ruler's meeting with heretics is modeled on the description of the denunciation of them by the Emperor Alexius Comnenus (1081-1118), written by his daughter, princess Anna Comnena. The emperor himself managed to expose the leader of the Byzantine Bogomils, Basil, by feigning an interest in the foundations of this heretical doctrine.

Under the rule of Bulgarian Tsar Ivan Asen II, a historical account appears in the Synodicon about the restoration in 1235 of the Bulgarian Patriarchate, 
which again became independent from Constantinople. After that, detailed historical stories disappear, giving way to specific historical facts connected with the memories of tsars, tsarinas and the nobility of the Second Bulgarian Tsardom: the cousins of Ivan Asen, the sevastokerators Alexander, Stresz and the despot Alexis Slav, Tsar George I Terter (1280-92), Bulgarian Tsar Ivan Shishman (1371-95), Patriarch Euthymius of Tarnovo and other historical figures.

Over the course of many centuries, the Synodicon of Tsar Boril played an important role in preserving the Bulgarians' historical memory of their medieval past. As an integral component of religious practice, it was read during the holiday, accompanied by hymns, and thus served as a means of disseminating information about their native history not only among the noble laity, but also the common people. Above all, the Synodicon' contributed to the formation of the historical consciousness of the Bulgarian people.

Translated by the author

\section{BIBLIOGRAPHY}

Angelov D. Bogomilstvoto v Balgariya. Sofia, 1969.

Angelov B. St Boriloviyat sinodik // Proslava na Veliko Tarnovo. Sbornik. Sofia, 1978. S. $182-86$.

Bozhilov I, Totomanova A.-M., Bilyarski I. Borilov sinodik. Izdanie i prevod. Sofia, 2010. Mircheva E. Boriloviyat sinodik - prevod, interpolatsii, redaktsii // Tarnovska knizhovna shkola. T. 9. Tarnovo i ideyata za hristiyanskiya universalizam (XII-XV v.). Veliko Tarnovo, 2011. S. 248-66.

Petrov S, Kodov H. Starobalgarski muzikalni pametnitsi. Sofia, 1973.

Polyvannyj DI. Istoriografiya v kontekste liturgii (zamečaniâ o Sinodike bolgarskoj cerkvi) // Formy istoričeskogo soznaniya ot pozdnej antičnosti do èpohi vozroždeniya (issledovaniya i teksty). Ivanovo, 2000.

Popruzhenko M.G. Synodic tsarya Borila. Odessa, 1899.

Popruzhenko M.G. Synodic tsarya Borila // Balgarski starini. Kn. 8. Sofia, 1928.

Totomanova A.-M. Sinodik carya Borila v sbornike Palauzova (NBKM № 289) // XXI Ežegodnaya bogoslovskaya konferenciya Pravoslavnogo Svyato-Tihonovskogo gumanitarnogo universiteta, 2011, № 21, T. 1. S. 165-71.

Totomanova A.-M. The Synodikon of Orthodoxy in Medieval Bulgaria // Studia Ceranea, 2017, № 7. P. 169-227.

Turilov A.A, Nikitin SI. Borila carya sinodik // Pravoslavnaya ènciklopediya. T. 6. Moskva, 2003, S. 27-8.

Velikov Yu. Boriloviyat Sinodik v svetlinata na svetootecheskoto nasledstvo // Tarnovska knizhovna shkola. T. 10. Tarnovskata darzhava na Duha. Veliko Tarnovo, 2015. S. 802-17.

\section{ILLUSTRATIONS}

1. Leather cover of the Synodicon of Tsar Boril. Palauzov copy, 14th century.

2. Cover of the Synodicon of the Palauzov copy with later postscripts. 
3. Third page from the Synodicon of the Palauzov copy with floral ornaments.

4. Excerpt from the Synodicon of the Drinov copy (16th century) with commemorations to the Bulgarian tsars and St Constantine-Cyril, Equalto-the-Apostles.

5. Page from the Palauzov copy with the mention of the pious Tsar Boril.

6. The Synodicon of Boril. Palauzov copy with musical notes and an indication of their unknown author.

7. Part of the Synodicon of the Palauzov copy (Greek prototype).

8. M. S. Drinov, whose name is given to the copy of the Synodicon from the 16th century.

9. N. H. Palauzov, cousin of the first publisher of the source, S.N. Palauzov.

10. The cover of Popruzhenko's book with the publication of the full text of the Synodicon based on the Drinov and Palauzov copies.

11. The cover of the first Popruzhenko's edition of the Synodicon (Palauzov copy). 